Revista Brasileira de Agricultura Irrigada v.11, nº.5, p. 1670 - 1676, 2017

ISSN 1982-7679 (On-line)

Fortaleza, CE, INOVAGRI - http://www.inovagri.org.br

DOI: $10.7127 /$ rbai.v11n500746

Protocolo 746.17 - 23/05/2017 Aprovado em 31/08/2017

\title{
DEVELOPMENT AND EVALUATION OF AN IRRIGATION MANAGEMENT TOOL
}

Angel Ricardo Caporale ${ }^{1}$; José Alberto Alves de Souza ${ }^{2}$; Thaís Carvalho. Camelo ${ }^{3}$; Carlos Elísio Cotrim ${ }^{4}$

\begin{abstract}
This study aimed to develop a tool for irrigation management and to evaluate its performance. To this end, 10 lysimeters, developed from plastic buckets, $20 \mathrm{~L}$ in volume, were installed. The inner volume of the buckets was divided into two parts. The lower half was filled with water. The upper half was filled with soil, grown with Bermuda grass. In the interior of the soil, a porous capsule was installed, connected to a plastic tube, which the lower border was immersed into the water of the lower part. As the crop extracted water from the soil, the soil sucked water from the lower part through the porous capsule. By lowering the water level in the bucket between two periods, the initial level was restored by addition of water through the feeder tube. The volume of water spent to restore the initial level divided by the bucket superficial area determines the evapotranspiration in that period. The tool was called Simplified Lysimeter - SIL. To evaluate the performance of the SIL, the following were considered: the correlation (r) and determination $\left(\mathrm{r}^{2}\right)$ coefficients, Willmott agreement (d), and Camargo \& Sentelhas performance (c) and standard error estimate (SEE), taking PenmanMonteith-FAO as reference. According to results obtained, the SIL, developed with easily accessible and low cost materials and easy to construct, had a performance classified as very good and overestimated the evapotranspirarion obtained by PM at $0.30 \mathrm{~mm} \mathrm{~d}^{-1}$, on average, showing good operating conditions and allowing to estimate evapotranspiration in agreement with Penman-Monteith estimates.
\end{abstract}

Keywords: lysimeter, evapotranspiration, Penman-Monteith.

\section{DESENVOLVIMENTO E AVALIAÇÃO DE UMA FERRAMENTA PARA MANEJO DE IRRIGAÇÃO}

\section{RESUMO}

\footnotetext{
${ }^{1}$ Estudante, Mestrado Profissional em Produção Vegetal no Semiárido, IF Baiano, Guanambi, BA.

${ }^{2}$ Professor, Doutor, Mestrado Profissional em Produção Vegetal no Semiárido, IF Baiano, Distrito de Ceraíma, CEP: 46430-000, Guanambi, BA, Fone: (38)99215-0030, Email: albertojanauba@gmail.com.

${ }^{3}$ Estudante, Mestrado Profissional em Produção Vegetal no Semiárido, IF Baiano, Guanambi, BA.

${ }^{4}$ Professor, Doutor, Mestrado Profissional em Produção Vegetal no Semiárido, IF Baiano, Guanambi, BA.
} 
Este estudo objetivou desenvolver uma ferramenta para manejo de irrigação e avaliar seu desempenho. Para isso, foram instalados 10 lisímetros, desenvolvidos a partir de baldes plásticos de $20 \mathrm{~L}$. O volume interno dos baldes foi dividido em duas partes. A metade inferior foi preenchida com água e a superior com solo, cultivado com grama Bermuda. No interior do solo, foi instalada uma cápsula porosa, conectada à água da parte inferior por um tubo plástico. À medida que a cultura extraía água do solo, este succionava água da parte inferior, através da cápsula porosa. O volume gasto entre dois períodos de tempo era reposto através do tubo alimentador. Este volume, dividido pela área superficial do lisímetro, permitia determinar a evapotranspiração nesse período. A ferramenta foi denominada de Lisímetro Simplificado - LIS. O método de Penman-Monteith-FAO (PM) foi utilizado como referência. Para avaliação do desempenho do LIS, foram considerados os coeficientes de correlação (r) e determinação $\left(\mathrm{r}^{2}\right)$, índice de concordância de Willmott (d), e de desempenho (c) de Camargo \& Sentelhas e erro padrão de estimativa (EPE). De acordo com os resultados obtidos, o LIS, desenvolvido com materiais de fácil acesso e de baixo custo e de fácil construção, teve desempenho classificado como muito bom e superestimou a evapotranspiração obtida por PM em $0,30 \mathrm{~mm} \mathrm{~d}^{-1}$, em média, apresentando boas condições de funcionamento e permitindo a obtenção de medidas de evapotranspiração em concordância com as estimativas realizadas pelo método de Penman-Monteith.

Palavras-chave: Lisímetro, evapotranspiração, Penman-Monteith.

\section{INTRODUCTION}

The water deficit is one of main characteristics of the Brazilian semi-arid region. Rainfalls are scarce, irregular and, in addition, the region has high evaporative demand, due to the high incidence of sunlight. In these conditions, where the water source is sufficient, irrigated agriculture is an excellent alternative of production, with high yield and quality production. However, irrigation must be performed efficiently with respect to use of labor force, energy, and water consumption. Therefore, water saving would be relevant, with a positive impact on its use, since irrigation is the activity that most uses this natural resource (OLIVEIRA et al., 2010).

Evapotranspiration (ET) is one of the main variables of the hydrological cycle. It consists of the process of water transfer to atmosphere, resulted from direct evaporation of soil water and transpiration of plant tissues (TAGLIAFERRE et al., 2010). It is known that ET occurs in a varied way during a crop cycle, being influenced by local edaphoclimatic conditions and characteristics of the crop.

Crop water requirement can be estimated by knowing local evapotranspirometric demand and crop coefficient. However, obtaining these data is not simple. There are operational difficulties and high spatial variation, even in small areas.

There are several methods for the determination of ET of the crop, and its can be divided into direct or indirect. Indirect ones require data of different meteorological elements and, often, the models are applied in regions different of those for which them were developed, being necessary adjustments for each region. In direct determination, lysimeters are considered accurate methods and allow the obtainment of real crop ET in the field. However, they are difficult to construct and to operate by small farmers, thus, their use are restrict to research institutions and specialized labor. They consist of tanks or containers constructed of different materials and sizes, filled with an amount of soil, and it must be installed under same conditions of the crop under study and the area where the evapotranspiration will be measured.

In 1990, the Food and Agriculture Organization (FAO) established a new definition for a reference crop and for the method that could estimate ET for this reference (PEREIRA et al., 1997). Based on this proposed new concept, the widely used and recommended method to estimate reference 
evapotranspiration (ETo) was developed by Penman-Monteith, who after established methodologies and criteria to calculate ETo that met the new definition of reference crop, started to be named as Penman-Monteith Method - FAO, (Allen et al., 1998).

In view of above and in order to determine the reference evapotranspiration by direct method, this work aimed to develop a low cost, easy to construct and use, and simplified lysimeter or evapotranspirometer; and to evaluate its performance in the field, taking Penman-Monteith standard method FAO as reference.

\section{MATERIALS AND METHODS}

The study was developed in an experimental area of the Instituto Federal de Educação, Ciência e Tecnologia Baiano Guanambi Campus, Ceraíma district, located at $14^{\circ} 17^{\prime}$ South Latitude and $42^{\circ} 41^{\prime}$ West Greenwich Longitude, and altitude $546 \mathrm{~m}$. The characteristic climate of the region, according to Köppen classification, is BSwh, warm climate of caatinga; summer rains and well defined dry winter period. Average annual temperatures are high, approximately $26^{\circ} \mathrm{C}$.

An automatic meteorological station was installed near experimental area in order to obtain daily meteorological data: minimum, mean, and maximum temperature $\left({ }^{\circ} \mathrm{C}\right)$, solar radiation $\left(\mathrm{MJ} \mathrm{m}^{2} \mathrm{~d}^{-1}\right)$, relative air humidity (\%) and wind speed $\left(\mathrm{m} \mathrm{s}^{-1}\right)$. Data were used to determine ETo ( $\mathrm{mm} \mathrm{dia}^{-1}$ ) by PM Method, recommended and parameterized in FAO Bulletin No. 56 (ALLEN et al., 1998).

The tool developed for irrigation management consists of an evapotranspirometer, or simplified lysimeter, that has the function of determining ETo or crop evapotranspiration. Its principle of operation is based on the suction of unsaturated soils, which can be described as the energy with which it absorbs water when it is free to move. It is important to note that this movement occurs from one point of greater to another of lower state of energy. This suction power is basically a function of mineralogy, density, and moisture of the soil.

In order to promote the primordial function as interface between soil and water of the reservoir, a porous capsule (ceramic water filter candle) was installed into the soil. This capsule establishes a hydraulic continuity through its pores until an energy balance occurs.

The Simplified Lysimeter - SIL was developed from plastic containers (buckets), with $20 \mathrm{~L}$ volume, $335 \mathrm{~mm}$ in height and 290 $\mathrm{mm}$ in upper diameter. The lid of the bucket was used to divide the inner area of the container into two parts. The lower compartment was used as water reservoir; with capacity for $8 \mathrm{~L}$. The upper one was used to accommodate the soil. The lid was cut off at its edge to get a 272 mm diameter disc so as to fit the inner diameter of the bucket at $135 \mathrm{~mm}$ from the bottom. Galvanized wires were installed under the disk in order to support the disc and, therefore, the soil mass, $10 \mathrm{~mm}$ above the maximum water level. Thus, an empty space of $10 \mathrm{~mm}$ was formed between water and soil. In the center of the disk, a 14 mm orifice was made to connect the porous capsule to the water reservoir through a plastic tube with $120 \mathrm{~mm}$ long and $7 \mathrm{~mm}$ internal diameter.

A transparent tube was connected to the reservoir and its upper extremity was attached in the outer side of the bucket. So, this tube serves to monitor the water level and as a drain. The level zero (maximum level of water in the transparent tube) was demarcated on the outer wall of the SIL. Finally, a $1 / 2$ " PVC tube with $360 \mathrm{~mm}$ length was installed at $50 \mathrm{~mm}$ away from the inner wall of the bucket. This tube serves to refuel the consumed water. Its lower extremity was beveled end to avoid clogging (Figure 1). 


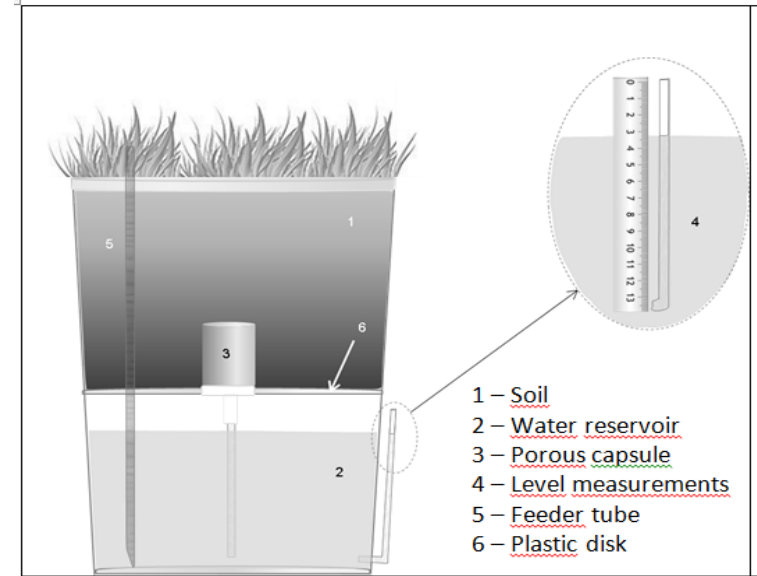

Figure 1. Illustrative Design of the Simplified Lysimeter - SIL. Source: Caporale, 2017

The water daily consumed by evapotranspiration process was determined by variation of water level in the transparent tube. At each reading, the reservoir was refueled using a $1000 \mathrm{~mL}$ graduated cylinder until the bottom of the bulb in the transparent tube reached the mark of level zero. The volume of water that was consumed daily was recorded.

Then, spreadsheets were used to organize and totalize data in time scale of $1,3,5$, and 7 days, referring to 90 days of observations, from May 20 to August 18, 2016.

Ten Lysimeters were installed in the center of the experimental area, arranged and leveled on the ground and spaced $2 \mathrm{~m}$ apart. Initially, the Lysimeters were filled with a layer of gravel No. 1 with $03 \mathrm{~cm}$ thickness, followed by a second layer of coarse sand with $01 \mathrm{~cm}$ thickness, and completed with soil of the experimental area, in reverse order of their removal, obeying the sequence in the original soil profile. The grass grown on Lysimeters surround was Bermuda (Cynodon dactylon L.), thin leaf. The choice for this species was made considering easy acquisition of seed and rapid establishment of the crop. The maintenance cuts were performed every time the grass reached $15 \mathrm{~cm}$ in height, lowering it to $12 \mathrm{~cm}$, as recommended by Reichardt and Timm (2004), in the description of the reference crop.

The SIL soil field capacity (FC) was determined and the Gravimetric Humidity was monitored biweekly by Oven-drying Method throughout the experiment to verify if it was consistent with the FC.
The analyzis were performed with data of 1, 3, 5 and 7 days of ETo, in mm day ${ }^{-1}$, during a period of 90 days of observations, using the regression analysis, considering the linear model $\mathrm{y}=\mathrm{bx}+\mathrm{a}$; In which, the dependent variable was the ETo obtained by PM Method and the independent variable the ETo values measured by SIL. Adjustments of the regression models were analyzed by means of the "t" test of Studant, at 5\% probability.

The methodology used to compare the results was proposed by ALLEN et al. (1986) and adopted by JENSEN et al. (1990), which is based on the standard error estimate (SEE), calculated through Equation 1, where the PM method is considered as standard.

$$
\operatorname{SEE}=\left(\frac{\Sigma(Y-\hat{y})^{2}}{n-1}\right)^{\frac{1}{2}}
$$

where,

SEE - standard error estimate, $\left(\mathrm{mm} \mathrm{d}^{-1}\right)$;

y - reference evapotranspiration obtained by PM Method, $\left(\mathrm{mm} \mathrm{d}^{-1}\right)$;

$\hat{y}$ - reference evapotranspiration measured by SIL, $\left(\mathrm{mm} \mathrm{d}^{-1}\right)$;

$\mathrm{n}-$ total number of observations.

The approximation of ETo values obtained by a given method in relation to values obtained with use of standard method was calculated by the index called concordance or adjustment, represented by the letter "d" (WILLMOTT et al., 1985). The range of values of $d$ index varies from zero, for a complete dispersion among values, to 1 , for a perfect agreement, calculated through Equation 2:

$\mathrm{d}=1-\frac{\sum_{\mathrm{i}-1}^{\mathrm{N}}(\mathrm{Pi}-\mathrm{Oi})^{2}}{\sum_{\mathrm{i}-1}^{\mathrm{N}}[(|\mathrm{Pi}-\overline{\mathrm{O}}|)]+[(|\mathrm{Oi}-\overline{\mathrm{O}}|)]^{2}}$

where,

d - index of concordance or adjustment;

$\mathrm{Pi}$ - reference evapotranspiration measured by SIL, $\left(\mathrm{mm} \mathrm{d}^{-1}\right)$;

Oi - reference evapotranspiration obtained by PM Method, $\left(\mathrm{mm} \mathrm{d}^{-1}\right)$;

$\overline{\mathrm{O}}$ - average of reference evapotranspiration obtained by PM Method, $\left(\mathrm{mm} \mathrm{d}^{-1}\right)$; 
$\mathrm{N}$ - total number of observations.

In order to obtain the performance of the evaluated models, it was used the "c" confidence or performance index, proposed by CAMARGO \& SENTELHAS (1997), which is the product of the correlation coefficient " $r$ " by concordance index "d".

The evaluation of performance of observed methods was given according to the classification in Table 1.

Table 1. Classification of the confidence or performance index (c)

\begin{tabular}{cc}
\hline Value of "c" & Performance \\
\hline C $>0,85$ & Óptimum \\
0,76 a 0,85 & Very good \\
0,66 a 0,75 & Good \\
0,61 a 0,65 & Median \\
0,51 a 0,60 & Tolerable
\end{tabular}

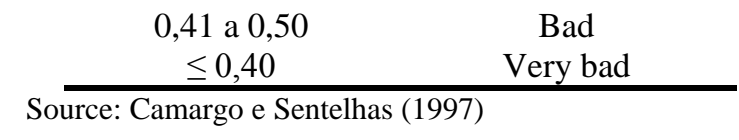

\section{RESULTS AND DISCUSSION}

In the Table 2 are presented comparisons between ETo values obtained by SIL method with values estimated by PM method; Coefficients "a" and "b" of the regression equation; Coefficient of determination $\left(\mathrm{r}^{2}\right)$; Standard Error Estimate (SEE); Correlation coefficient (r); The Willmontt's concordance index (d); Confidence index or performance (c); ETo values $\left(\mathrm{mm} \mathrm{d}^{-1}\right)$ for periods of one, three, five and seven days.

Table 2. Performance parameters and regression analysis of average ETo calculated by PenmamMonteith method - FAO 56 (PM) in relation to Simplified Lysimeter - SIL

\begin{tabular}{|c|c|c|c|c|c|c|c|c|c|}
\hline \multicolumn{10}{|c|}{ Daily } \\
\hline Methods & $\mathrm{a}$ & $\mathrm{b}$ & $\mathrm{r}^{2}$ & SEE & $\mathrm{r}$ & $\mathrm{d}$ & C & Classification* & ETo average (mm) \\
\hline PM & - & - & - & - & - & - & - & - & 5,73 \\
\hline SIL & 1,079 & 0,767 & 0,71 & 0,52 & 0,84 & 0,89 & 0,75 & Good & 6,03 \\
\hline \multicolumn{10}{|c|}{ Three days } \\
\hline SIL & 1,143 & 0,756 & 0,74 & 0,42 & 0,86 & 0,89 & 0,77 & Very good & 6,03 \\
\hline \multicolumn{10}{|c|}{ Five days } \\
\hline SIL & 1,330 & 0,725 & 0,74 & 0,38 & 0,86 & 0,87 & 0,76 & Very good & 6,03 \\
\hline \multicolumn{10}{|c|}{ Seven days } \\
\hline SIL & 0,845 & 0,805 & 0,82 & 0,32 & 0,91 & 0,88 & 0,80 & Very good & 6,03 \\
\hline
\end{tabular}

The calculated SEE value for the LIS method was $0.52 \mathrm{~mm} \mathrm{~d}^{-1}$, for daily estimates, which decrease as it increases the estimation period, up to $0.32 \mathrm{~mm} \mathrm{~d}^{-1}$ for 7 days period. The SIL overestimated the mean ETo by 0.30 $\mathrm{mm} \mathrm{d}^{-1}$, which corresponds to $4.5 \%$ more than that estimated by standard method. Probably, this overestimating of ETo values by SIL could be attributed to overexposure of Lysimeter walls to solar radiation and advective heat effects from droughts areas around, since they were installed on the ground rather than buried, although the grass in the experimental area was maintained at a height equal to the edge of the Lysimeters.

PEREIRA et al. (2001), studying operational problems with weighing lysimeters during the rainy season and on dry days with gusts of wind, accentuate the need to be rigorous with the boundary conditions aiming to decrease the advective effects, especially in times of greater evapotransprometric deficit. In fact, difficulties in maintaining internal and external conditions of the lysimeters with same characteristics are evident, according to SEDIYAMA (1996), because normally, plants tend to grow more inside of lysimeters than off them or beyond of their limits (bouquet effect).

Comparison with standard method provided " $r$ " and " $d$ " values equal to 0.84 and 0.89 , respectively, for daily estimates, which reflected a good fit of the regression model, with "c" index equal to 0.75 , according to the criteria of CAMARGO \& SENTELHAS (1997).

All coefficients were improved as the interval of evaluation was increased and presented $r^{2}$ values equal to $0.74,0.74$ and 0.82 
and confidence "c" index equal to $0.77,0.76$ and 0.80 , for periods of 3,5 and 7 days, respectively, being classified as very good.
Figure 2 shows up the graph of trend and magnitude of ETo during the study period on a daily scale between SIL and PM methods.

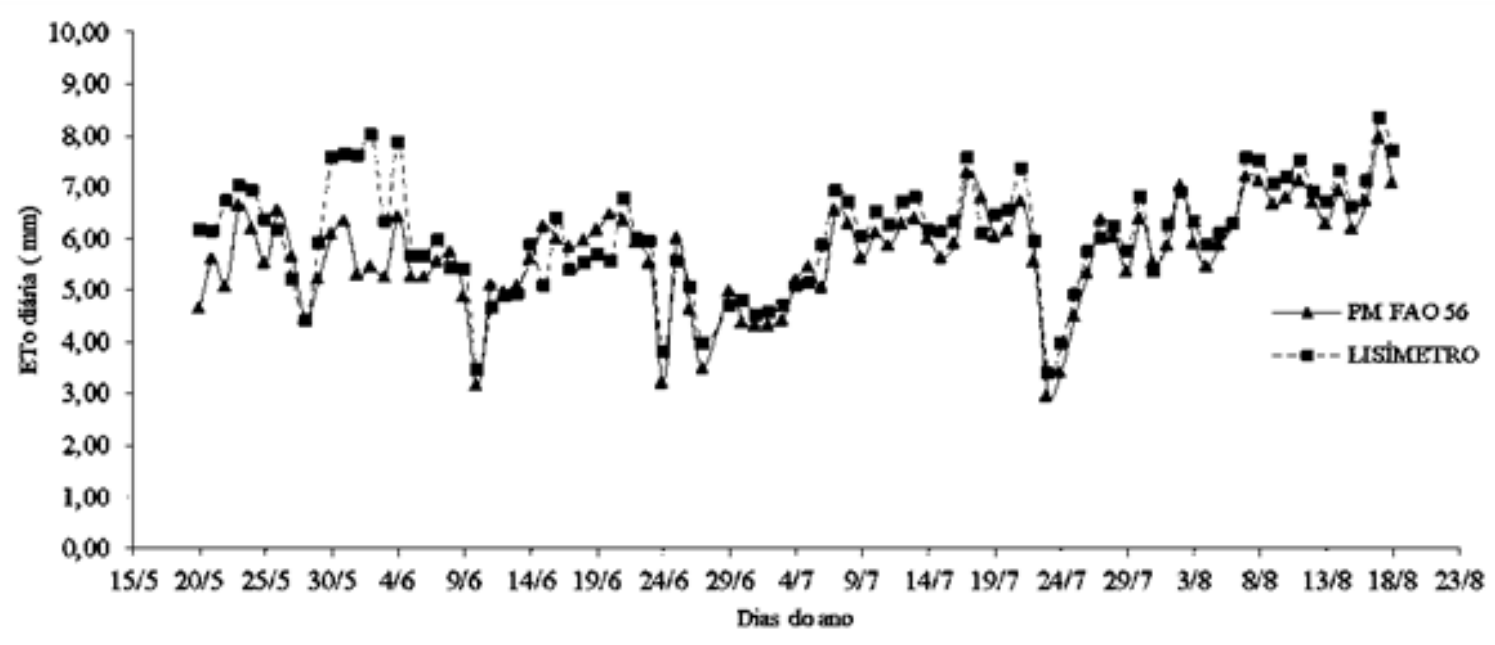

Figure 2. Evolution of reference evapotranspiration (ETo), between the Simplified Lysimeter - SIL method and Penman-Monteith method - FAO 56, for period from May 20 to August 18, 2016.

It is observed that, considering the trend, the SIL method curve shows similarity with the PM ETo curve during most of the studied period. This means that, in general, ETo increases and decreases in value simultaneously in both ETo and PM methods.

Considering that the methodology developed and results presented in this study to obtain evapotranspiration are still incipient, but very promising, further studies should be carried out aiming at improvements for a safe validation of the method. It is intended that SIL should be a method used by producers to obtain simple and reliable evapotranspiration measures, and thus, the irrigation management be carried out satisfactorily. An adequacy will be made in the SIL to allow it to be buried, so that the level of the crop into the SIL be the same level of the external soil, which will probably minimize the overestimation of ETo in the SIL. Therefore, a new way of reading the evapotranspirated volume is being adopted in a new study that are carried out nowadays at Guanambi Campus in order to validate the tool.

\section{CONCLUSIONS}

The Simplified Lysimeter - SIL, developed with low cost and easily accessible materials, easy to construct and operate, had a very good performance, showing good operating conditions and allowing us to obtain evapotranspiration measurements in agreement with that estimates by Penman- Monteith method.

Daily variation of the ETo of the Lysimeter method according to considered climatic variables presented similar trend during the evaluation period with the ETo of Penman-Monteith method, with an overestimation of just 0.30 $\mathrm{mm}$ day $^{-1}$, indicating viability of the developed method.

The Lysimeter enabled daily estimation of evapotranspiration values throughout the observation period, with no interruptions in the readings, demonstrating viability of the methodology.

\section{BIBLIOGRAPHY}

ALLEN, R. G. A Penman for all seasons. Journal of Irrigation and Drainage Engineering. New York, v. 112, n. 4, p. 348386, 1986.

ALLEN, R.G. et al. Crop evapotranspiration Guidelines for computing crop water 
requirements. Rome: FAO, 1998. 300 p. (Irrigation and Drainage Paper 56).

CAMARGO, A.P.; SENTELHAS, P.C. Avaliação do desempenho de diferentes métodos de estimativa da evapotranspiração potencial no estado de São Paulo. Revista Brasileira de Agrometeorologia, Santa Maria, v.5, n.1, p.89-97, 1997.

JESSEN, M.E.; BURMAN, R.D.; ALLEN, R.G. Evapotranspiration and irrigation water requirements. New York, ASCE. 1990. 332 p.

OLIVEIRA, G. M.; LEITÃO, M. M. V B.R.; BISPO, R. C.; SANTOS, I. M. S.; ALMEIDA, A. C. Comparação entre métodos de estimativa da evapotranspiração de referência na região norte da Bahia. Revista Brasileira de Agricultura Irrigada v.4, n.2, p.104-109, 2010.

PEREIRA, A.R., VILLA NOVA, N.A.; SEDYIAMA, G.C. Evapo(transpi)ração. Piracicaba, SP: FEALQ, 1997. 183p.
PEREIRA, A.R.; SANTIAGO, A.V.; MAGGIOTO, S.R.; FOLEGATTI, M.V. Problemas operacionais com lisímetros de pesagem durante a estação chuvosa e em dias secos com rajadas de vento. Revista Brasileira de Agrometeorologia, v.10, n.1, p.51-6, 2001.

SEDIYAMA, G. C. Estimativa da evapotranspiração: histórico, evolução e análise crítica. Revista Brasileira de Agrometeorologia, Santa Maria, v.4, n.1, p.ixii, 1996.

TAGLIAFERRE, C.; SILVA, R.; ROCHA, F.; SANTOS, L. Estudo Comparativo de diferentes metodologias para determinação da evapotranspiração de referência em EunápolisBA. Revista Caatinga, Mossoró, v.23, n.1, p.103-111, 2010.

WILLMOTT, C.J.; ACKLESON, S. G.; DAVIS, R. E.; FEDDEMA, J. J.; KLINK K. M.; LEGATES, D. R.; O’DONNELL, J.; ROWE, C. M. Statistics for the evaluation and comparison of models. Journal of Geophysical Research, Ottawa, v. 90, n. 5, p.8995-9005, 1985. 